This manuscript is a preprint and has not been submitted for traditional publication yet, we have a few options in mind but have not formally submitted a manuscript. Please note that this article has not undergone peer-review and the manuscript has yet to be formally accepted for publication. Subsequent versions of this manuscript may have slightly different content. If accepted, the final version of this manuscript will be available via the 'Peer-reviewed Publication DOI' link on the right-hand side of this webpage. Please feel free to contact any of the authors; we welcome feedback. 


\title{
Potential environmental hazard due to tailings dam failure in Minnesota iron range and safety concern of the Dams in the US
}

\author{
Clara L. ${ }^{1}$, Fei Liu ${ }^{2}$ \\ ${ }^{1}$ New Jersey Science Academy \\ ${ }^{2}$ New Jersey Science Academy, Fei.Liu@njsci.org
}

\begin{abstract}
An ongoing debate [1] [2] centered around mining operations and tailings dam usage near the Minnesota mining range led to an investigation of potential environmental hazards near the cities of Hoyt Lakes and Embarrass. Topographic data from Satellite observations made available by USGS [3] and HEC-RAS [4] [5] developed by US Engineer Corp are used to simulate the extent of mud flow from a hypothetical tailings dam break at the proposed mining site. Simulation results indicate significant flooding and pollution in the city of Embarrass, the lakes near The Legend at Giants Ridge, and the Embarrass River flowing southwest. Parts of the mud flow can also reach the area northwest of Lost Lake. Recent dam breaks in Michigan prompted a survey of the dams across the entire US in connection with annual average precipitation and number of Earthquake statistics per State. The States with high precipitation and Earthquake events are especially vulnerable for dam breaches since precipitation and seismic activities are major causes of dam breach events. In conclusion, Dam breaches is a serious threat to the US water system, especially as the dams are aging and lack appropriate levels of maintenance. Finally we discuss additional work using different modes of failure and dam breach parameters that may affect the downstream flooding patterns simulated.
\end{abstract}

\section{Introduction}

In February 2005, Poly Met Mining, Inc. (PolyMet) made its first proposal to the Department of Natural Resources for a mining project in northern Minnesota, intended for the extraction of metals like copper, nickel, and platinum groups [6]. Since then, the project, known as the NorthMet project, has been undergoing environmental review. The entire project is operated by Glencore, a Switzerland-based mining company, that plans on building the mine on the Mesabi Iron Range in Saint Louis County, Minnesota. PolyMet estimates that the deposit will be mined to a depth of about 700 feet below the surface and span across approximately 19,000 acres of mines and processing sites, transportation corridor, and the existing tailings basin and buffer. Potentially, this mining project could mine 1.16 billion pounds of copper, 170 million pounds 
of nickel, 6.2 million pounds of cobalt, and over 1 million ounces of palladium and gold [7] PolyMet believes that it could open over 1000 jobs in the region. To accommodate this new mining operation, PolyMet had planned to use the existing tailings dam previously owned by LTV and augment the facility to store mining waste [8].

In most mineral extraction processes, large quantities of water are necessary for the extraction of minerals from ore. Tailings describe the remnant rock particles with a grain size distribution from medium sand to clay-sized particles that are usually deposited in slurry form inclusive of chemicals. A tailings dam is a type of dam mainly used in mining operations to store tailings. When tailings dam failures occur, the tailings often tend to liquefy and flow over a long distance (or sometimes travel along rivers), which can lead to both loss of life and environmental damage.

The purpose of a tailings dam is to store any byproducts from mining processes using rock to create a barrage. Large emphasis is placed on the design and structure of tailings dams as they can have extensive impacts on surrounding areas [9]. The upstream design, which consists of trapezoidal embankments stacked on top of one another, packs tailings into a stairlike configuration. Although using an upstream design is cheaper and more convenient than using other designs, this method requires that the tailings materials themselves are used to create a barrier, making the dam more unstable and prone to leakage [10]. Globally, there have been several incidents of upstream tailings dam breakage, most notorious, the catastrophic failure of the Brumadinho dam in Brazil, which killed over 248 people and costed over 2.4 billion US dollars in property damage in January 2019 [11. Although the upstream design is banned in parts of Canada, Brazil, Chile, Peru, and several other countries, the United States has yet to place this ban as an act of precaution for the potential economic and environmental impacts that a dam breakage would have on society. As PolyMet plans to build their dam with this upstream design, understanding its implications and potential effects over regions in St. Louis County is crucial.

One way to evaluate the impact of the mining dams on the local society is to simulate the mud flow from a potential dam break. HEC-RAS [4] [5] is a comprehensive software environment that's capable of integrating GIS technology [12] [13] with state of the art hydrograph simulations. Raman [14 used HEC-RAS to simulate the mud flow from the Brumdinho dam break. Mcdonald [15] used data collected from historical dam failures to access the dam breach characteristics such as the size of the dam breach, the shape of the dam breach, the time that is required for the breach to develop, and the reservoir water surface elevation at which breaching begins. Different causes of dam failure such as overtopping, seepage and piping, were also analyzed, which influenced the choice of dam failure reason chosen in this work. Froehlich [16] examined dam breach characteristics from 76 reported dam failures and summarized the result in an empirical model describing the final width of a trapezoidal breach along with its formation time. Lariyah [17] examined the breach flow hydrographs and generation of the inundation map at downstream areas in response to the proposed construction of Kahang Dam. Sidek [18] analyzed the dam break for Saddle Dam A with dam breach parameters predicted by Mcdonald [15]. Alvin [19] simulated the flooding pattern near North Carolina due to Hurricane Florence also using HEC-RAS. 


\section{Area of interest}

We examine and discuss the area that could be affected by a potential dam break at Hoyt Lakes. As seen in Figure 1 surrounding iron mine tailings dam, the following geographic locations are populated residential areas:

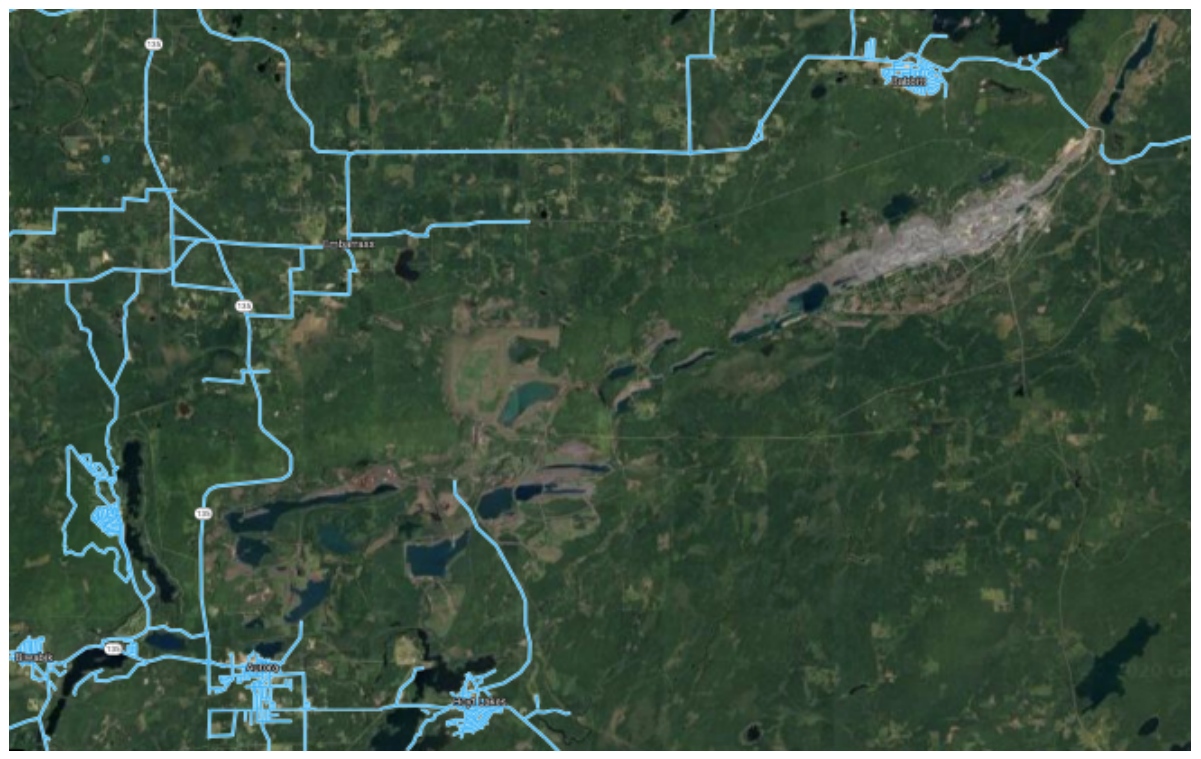

Figure 1: Local area of interest, graph shows the local highway and populated residential area surrounding the tailings dam right in the middle

1. $9.6 \mathrm{~km}$ south is Hoyt Lakes city with a population of over 2000 people, surveyed in 2010. The city is bordered by two lakes, making it a prime location for outdoor recreational activities and sports. The Country Inn of Hoyt Lakes has paved trails for activities like hiking, biking, skiing, and skating.

2. $11.3 \mathrm{~km}$ southwest is the city of Aurora, with a population of 1682 people as of 2010. It has three schools and several ATV and snowmobile trails on its outskirts. The area produces a large amount of America's iron and taconite ore.

3. $12 \mathrm{~km}$ west is the recreational area called The Legend at Giants Ridge and is known to be one of Minnesota's best golf resort destinations as well as one of the top golf destinations in the world.

4. $15 \mathrm{~km}$ northeast is a town named Babbitt with a population around 1500 people known for its outdoor activities such as fishing, camping, sight seeing. It also offers cultural and business opportunities.

5. The Evangelical Free Church of Embarrass is located northwest from the dam. This church had previously been burned down in 1982 but has continued to grow since then. They minister to over 100 families and an average of 210 people attend each worship service. People from many Minnesota cities such as Aurora and Hoyt Lakes also attend this church. 
6. The Lost Lake area north from Hoyt Lakes as part of the city of Mound and Lake Minnetonka. This is largely a tourist and resort area.

Located in the center of Figure 1 is the upstream tailings dam at Hoyt Lakes, similar to what failed in Brumadinho, Brazil killing 280 during the break. The dam has an estimated height of $250 \mathrm{ft}(70 \mathrm{~m})$, topographic data shows a height difference about 40 meters (460 meters to 500 meters) from the top of the dam to the surrounding base of the dam [3].

The recorded total annual precipitation over MN is 60.21 inches based on [20]. This is the highest number for the area on record. Polytech claims a rainfall of over 70 inch in 72 hours would be problematic [20]. The MN region is also relatively free of seismic activity [21] 22. Based on these findings, the LTV dams are relatively safe from exacerbated precipitation or seismic activity. However there has been reported leakage near the tailings dam [8], so structural instability would most likely be the cause of dam failures.

\section{Theory of dam break modelling}

The primary goal of this research is to study the flow of mud due to a tailings dam break and analyze its causes through rough modelling with flow analysis software (HEC-RAS)

The fundamental 2D shallow water equations in flux form solved by HEC-RAS 23] are

$$
\begin{aligned}
\frac{\partial \mathbf{U}}{\partial t}+\frac{\partial \mathbf{F}_{\mathbf{x}}}{\partial x}+\frac{\partial \mathbf{F}_{\mathbf{y}}}{\partial y} & =\mathbf{S} \\
\mathbf{U} & =\left[\begin{array}{c}
h \\
h u \\
h v
\end{array}\right] \\
\mathbf{F}_{\mathbf{x}} & =\left[\begin{array}{c}
h u \\
h u u+1 / 2 g h^{2} \\
h u v
\end{array}\right] \\
\mathbf{F}_{\mathbf{y}} & =\left[\begin{array}{c}
h u \\
h u v \\
h v v+1 / 2 g h^{2}
\end{array}\right] \\
\mathbf{S} & =\left[\begin{array}{c}
0 \\
-g h \frac{\partial z}{\partial x}-c_{f} u \\
-g h \frac{\partial z}{\partial y}-c_{f} v
\end{array}\right]
\end{aligned}
$$

where $\mathbf{U}$ is the state vector containing height and momentum of fluid, $\mathbf{F}_{\mathbf{x}}$ and $\mathbf{F}_{\mathbf{y}}$ are the flux vectors containing mass flux and momentum flux, $\mathbf{S}$ is the source term describing bottom topography and friction. The bottom friction coefficient $c_{f}$ can be calculated from the Manning formula $c_{f}=\frac{n^{2} g \sqrt{u^{2}+v^{2}}}{R}$ and is dependent on the Manning's coefficient $n$ [24]. HEC-RAS also adds Coriolis terms to the source term when instructed. 


\section{Dam Break Simulation}

Satellite based digital topographic data at a resolution 1/3 arc second (or equivalent 10 meters) over the cities of Hoyt Lakes and Embarrass is downloaded from USGS [3]. This digital elevation data set together with projection EPSG:26991 [25] information over north Minnesota are used in HEC RAS to create the computational domain for the mining site including the upstream tailings dam from LVT.

Due to the placement of the dam, which is near the ridge as shown Figure 2, a high ground, potential mud flow can travel in all directions to the surrounding low ground. To identify possible mud flow routes, initial trial runs are performed to study the flow pattern. A 2D flow area is established with the dam placed in the center of the $2 \mathrm{D}$ flow area. A gap has to be left open so the polygonal perimeter of the $2 \mathrm{D}$ flow area can close itself correctly. Throughout the study, a computational mesh of a resolution $100 \times 100$ meters is used for hydrograph modelling. This resulted in roughly 57000 number of computational cells where the previous shallow water equations are solved.

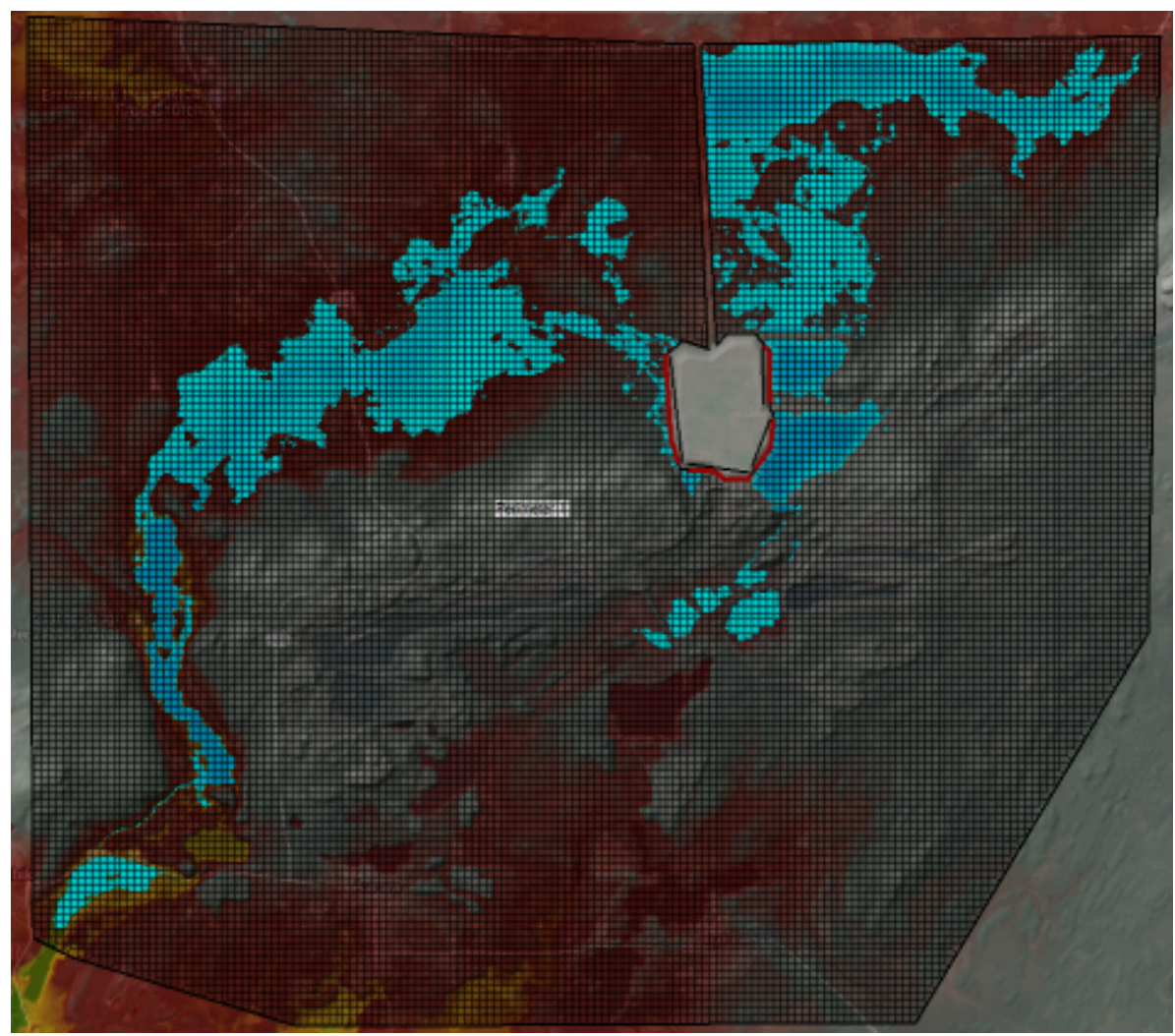

Figure 2: Resulting flow pattern from trial simulation where the 2D mesh surrounding the tailings dam has connection gap north from the tailings dam. As a result, the mud flow can be seen visibly cut off from the right and left side at the gap 


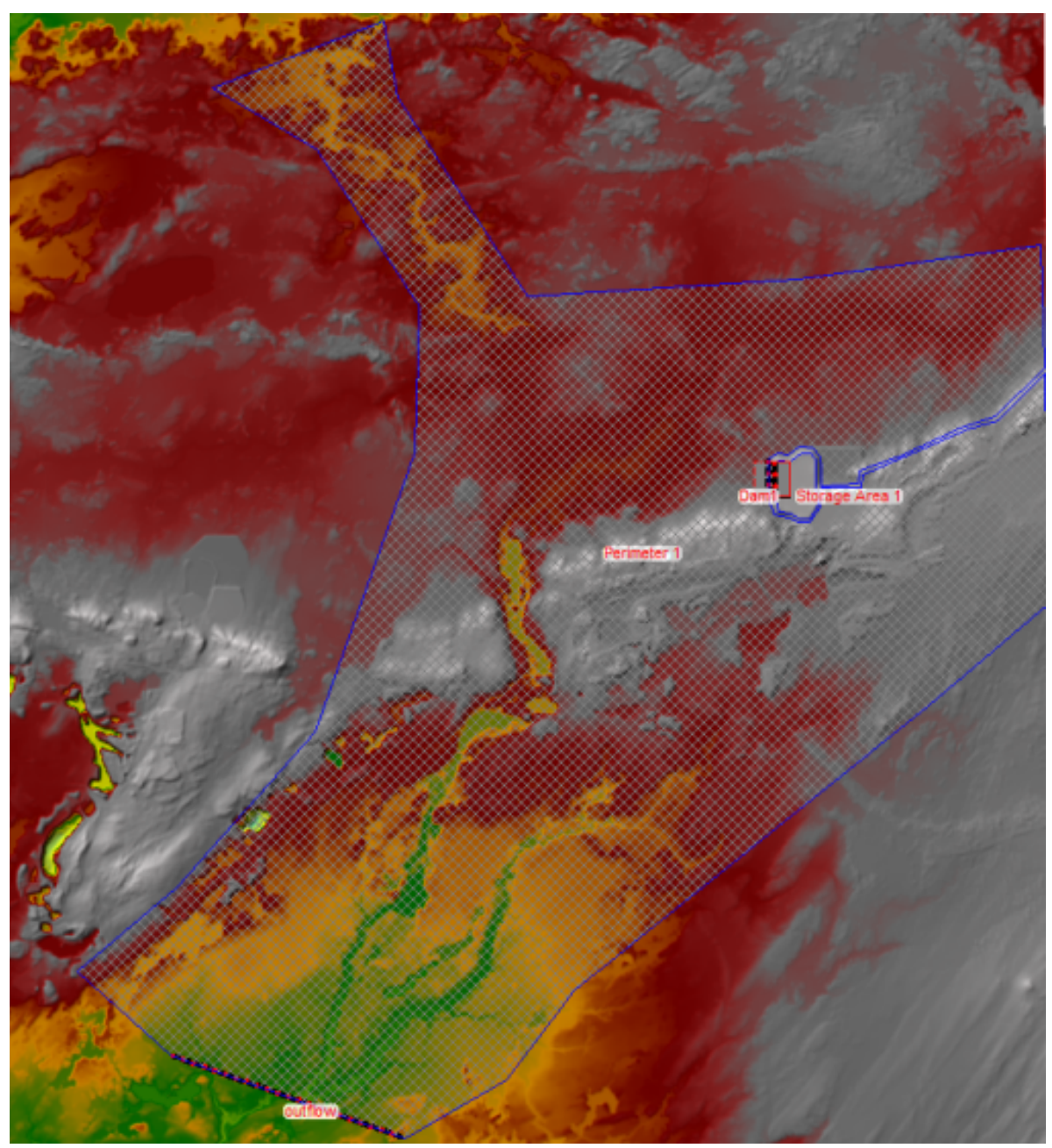

Figure 3: Final Mesh used in mud flow simulation including the dam placed near the west boundary of the storage area used as the dam. The mesh connection gap is placed on the mountain range east from the tailings dam. Due to the elevation of the mountain range, this connection gap does not lead significant bias in simulated mud flow result.

Hypothetical boundary conditions are placed around the dam with hydrograph outflow rates set up to simulate mud flow in the region. The results from this trial simulation suggest significant mud flow towards the northeast and southwest directions from the dam. Very little mud was able to cross the ridge to the south of the dam as shown in Figure 2.

In this trial setup, a perimeter gap is placed north from the dam, and the simulated results indicate mud would flow across the gap westward from the east side of the gap. In addition, we noticed east from the dam along the ridge, there is no significant mud flow. In the actual set up, we would place the gap east from the dam along the ridge where very little mud flow activity is observed due to the local higher ground.

The computational domain in the trial set up is more rectangular. The result indicates the flow extends mostly along the northeast-southwest direction. In the final setup as shown in figure 3. we would create a computational area along the diagonal direction with a bulge extending to the Lost Lake area. 


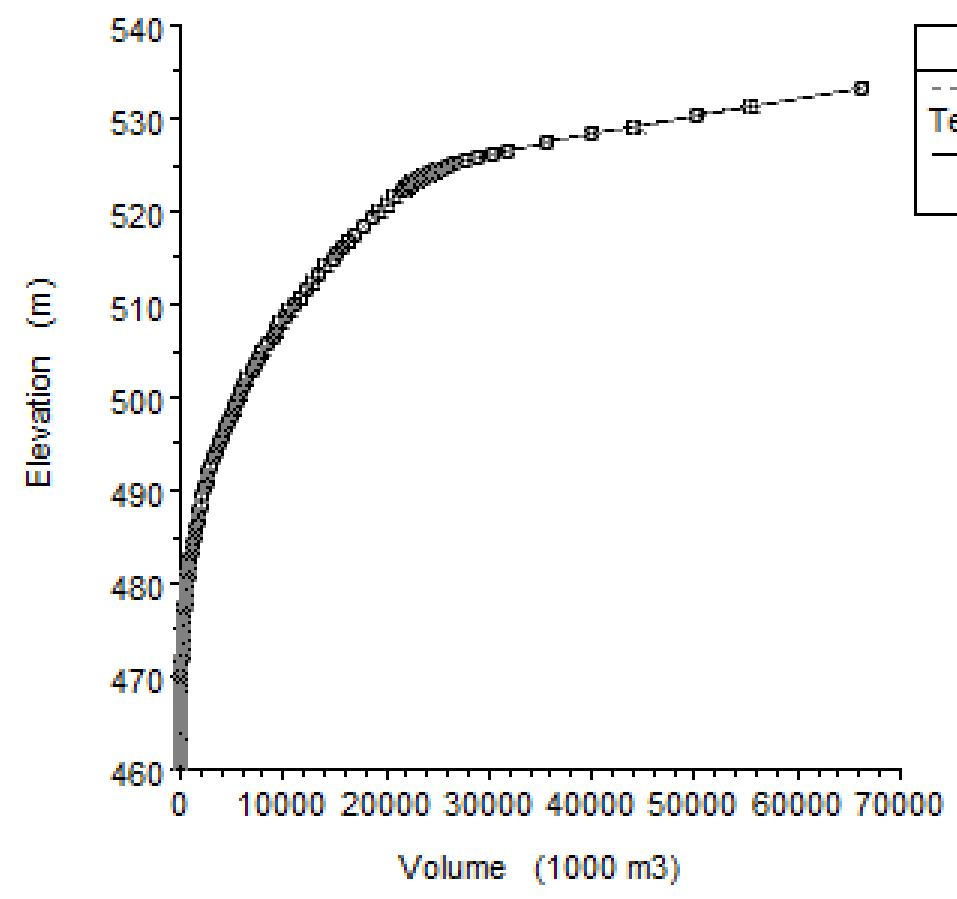

Figure 4: Volume of mud in tailings dam computed from Dam elevation and base area using HEC RAS
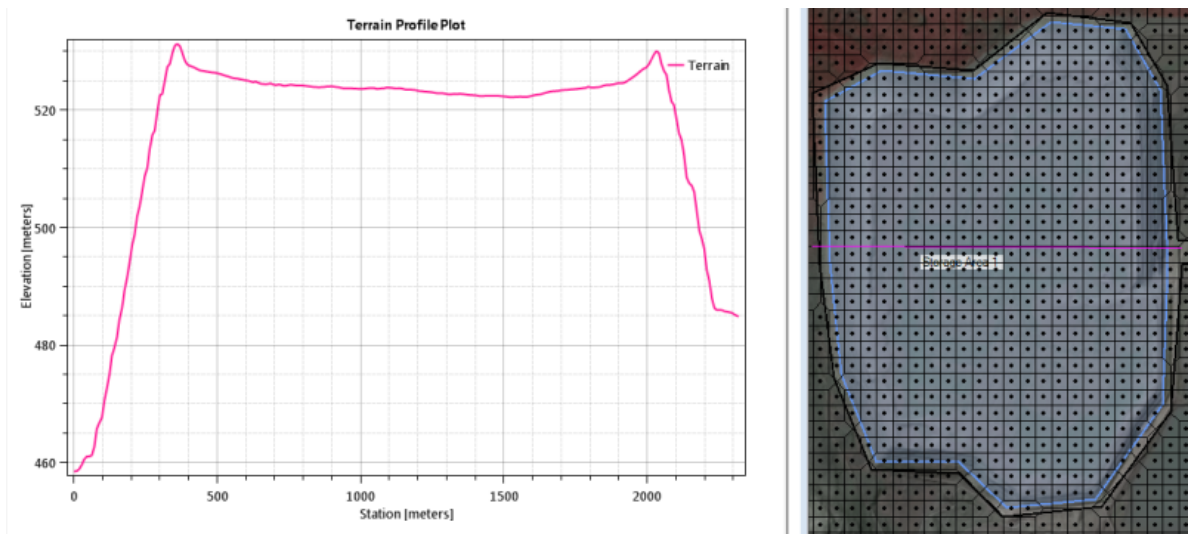

Figure 5: Elevation of the dam relative to the base using terrain profiling tool in HEC RAS

HEC RAS estimates that the total volume of mud stored in the main upstream tailings dam is about 66 million cubic meters using the builtin elevation vs volume curve. The base of the dam is 460 meters as shown in figure 4 and 5 . 


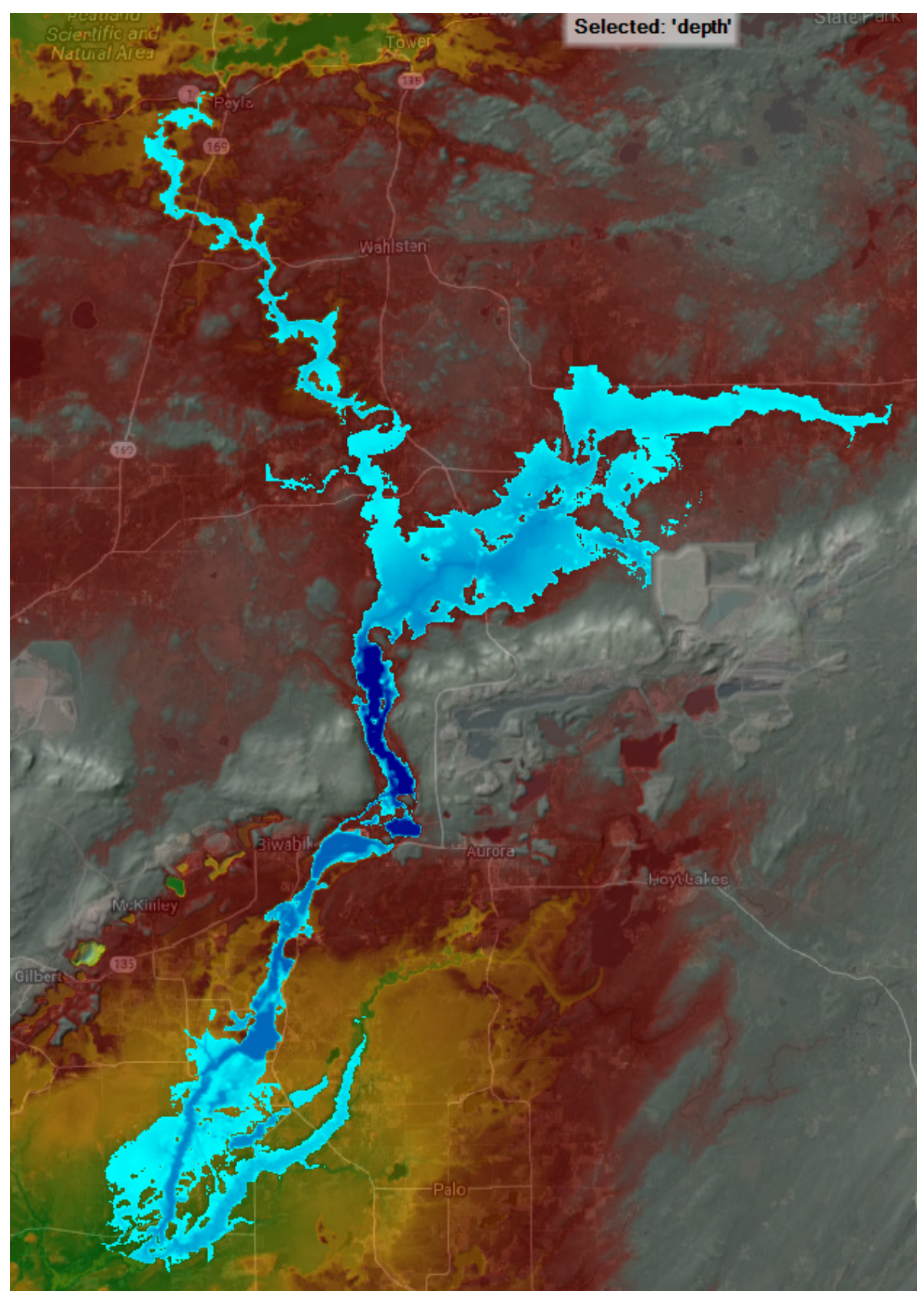

Figure 6: Simulated flooding pattern using the final mesh and breach placed on the west side of the tailings dam. Result indicates significant flooding along the lakes.

An initial dam is placed near the northwest direction as shown in Figure 3 and significant mud flow is observed through the 3 lakes near the legend at Giants Ridge: Sabin Lake, Wynne Lake, and Embarrass Lake as shown in Figure 6. The mud flow then continues southwest entering the lakes downstream. The dam outbreak could lead to pollution to the local water system, and local highway 135 could experience erosion as the mud flow passes the local highway.

In the process of modelling the mud flow, we found that HEC-RAS would occasionally lose the dam breach data. This caused the mud flow to be significantly reduced because the tailings 
dam failure does not occur even when the data has been previously recorded.

In addition, we discovered that when multiple dams are placed around a single storage area, the amount of mud flow gets multiplied and the potential energy thus the speed of the mud flow is also multiplied resulting in a mud flow with higher speed and depth.

Based on the results of the trial simulations, our final computational mesh Figure 3 covers the local area that's most susceptible to the extent of the mud flow due to potential dam break at the tailings dam. A dam is placed on the west boundary of the tailings dam. Other trials of dam placement indicate the pattern of mud flow is not significantly influenced by the dam placement as long as the dam is on the northern side of the tailings dam. This is due to the high ground of the mountain range south from the tailings dam. An outflow boundary is placed downstream of the Embarrass River to release the mud flow from the computational domain otherwise backflow due to reflection near the boundary causes unrealistic simulation results.

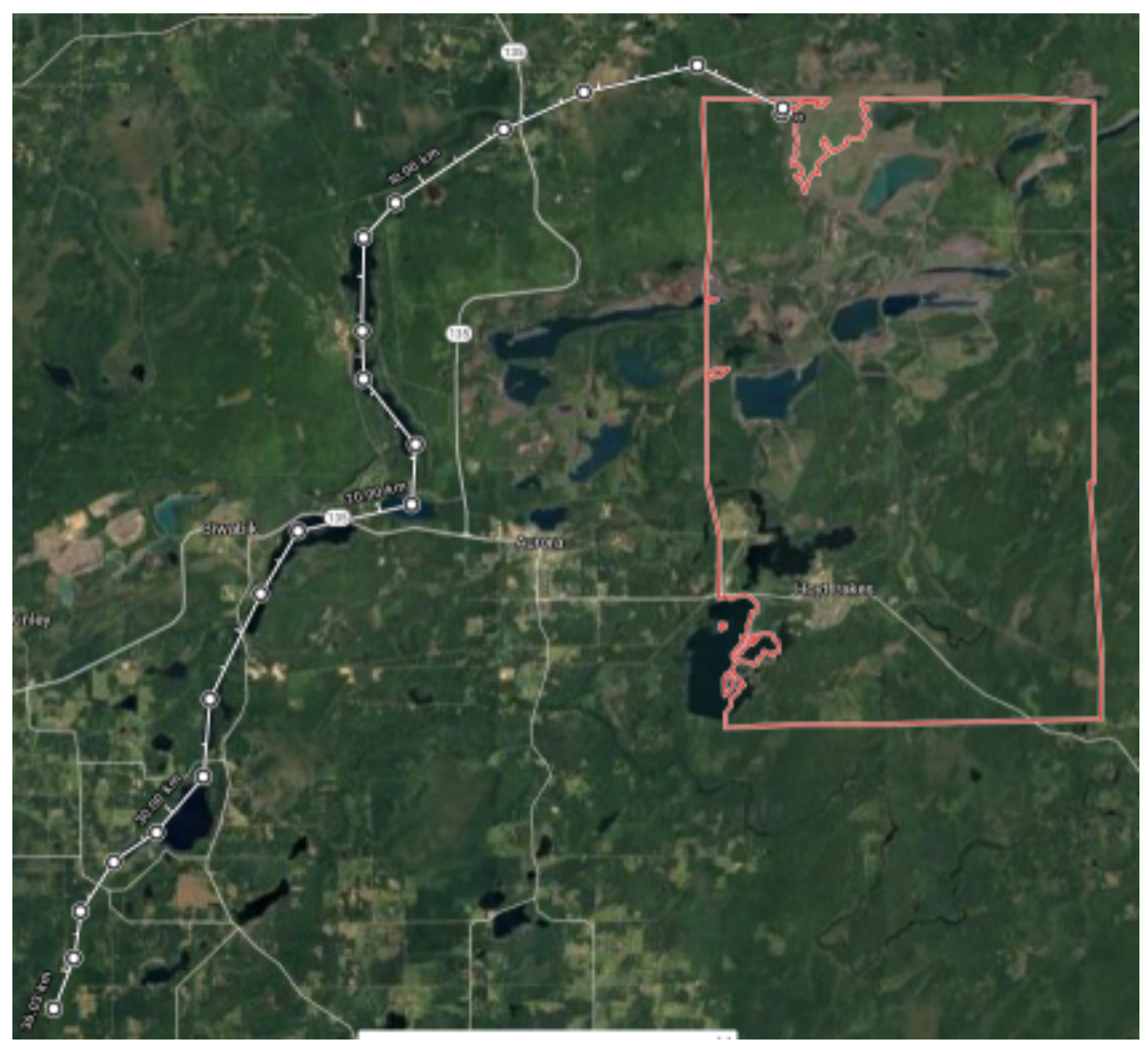

Figure 7: The main route of the simulated mud flow. After roughly 1.5 days, the mud from tailings dam breach travels roughly $36 \mathrm{~km}$ along the lakes surrounding the dam

The primary feature of the mud flow as shown in Figure 6 is the flooding of the canyon and the residential area southwest from the canyon. The canyon has 3 lakes Sabin Lake, Wynne Lake, and Embarrass Lake. They are completely flooded with an average depth of about 8 meters. The city of Embarrass is flooded and partially buried under mud. A branch of the mud flow extends northwest, flooding the area neighbouring the Evangelical Free Church of Embarrass. As shown in Figure 7, along the local river and lake system, the mud flow travels roughly $36 \mathrm{~km}$ in 1.5 
days.

\section{A survey of the Dams in the US}

As we are working on this project, on May 19, 2020, the Edenville Dam and Sanford Dam were broken due to severe flooding in central Michigan. The two dam breaks resulted in a call for a flash-flood warning for neighboring areas of the Tittabawassee River, and residents of several nearby towns were evacuated (Figure 8), including Edenville, Sanford, and Midland. Within Midland, about 10,000 people evacuated and another 1,000 individuals outside of the city were required to evacuate as well. According to the Weather Service, by Wednesday, the Tittabawassee River reached 34.71 feet by early morning, which is 10 feet above flood levels [26]. Due to the heavy rains that pushed the water levels of the lake, continuous flows of water continued down the Tittabawassee River overnight from Tuesday to Wednesday. Normally the Edenville and Sanford dams contain the Tittabawassee River to create two separate lakes, but the continuous rise of water resulted in dam breaches.

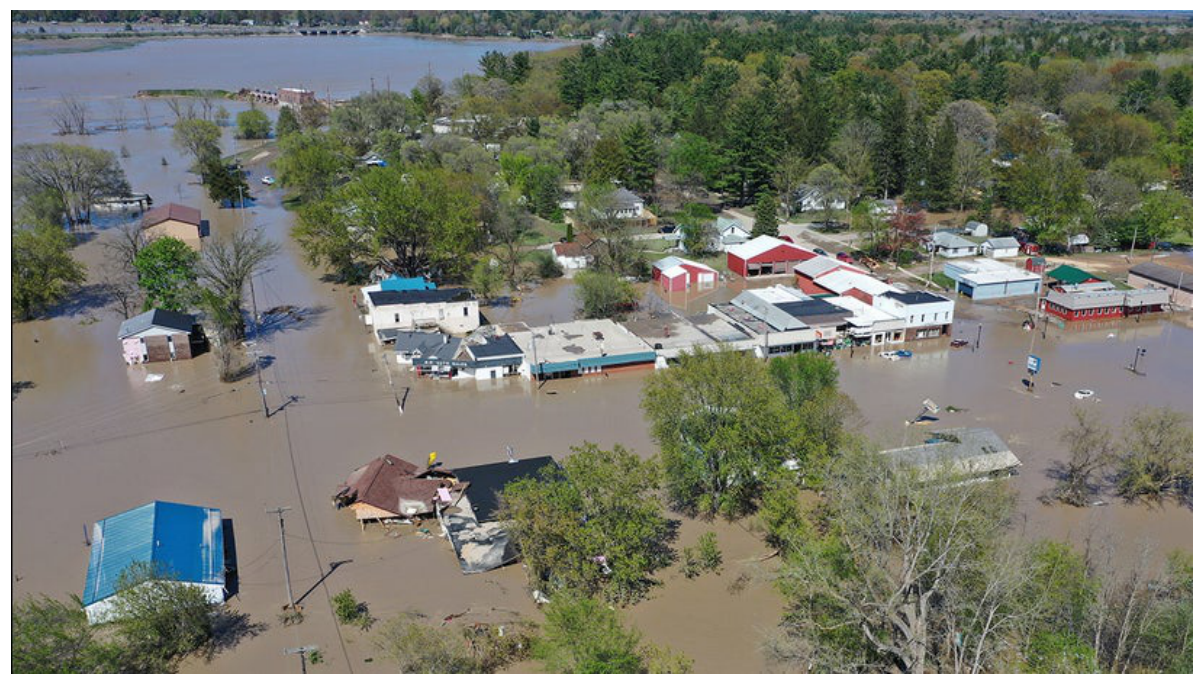

Figure 8: The aftermath of dam breaks in Michigan on May 19, 2020

While the Edenville and Sanford dams are the only two dams within Michigan that broke as a result of excessive amounts of precipitation, the state is still home to several other dams that are at risk of dam breakage. Of the 85 high hazard dams that are state regulated in Michigan, meaning they would have expected loss of life and severe impacts if broken, six are in poor conditions - one of which is the Edenville Dam [27]. One other specific dam is the Portage Plant Dam in St. Joseph County, which creates Hoffman Pond. Indicated in a 2013 brief inspection, the Portage Plant Dam was listed in poor condition. Built in 1922 according to the United States Army Corps of Engineers national inventory of dams, the structure is almost 100 years old [28]. Given that the Portage Plant Dam and Edenville Dam are only two of the many dams that are recorded to be or have been in bad condition, this only leaves implications for other dams in different counties and states. With the growing age of dams in America, many are becoming weak and susceptible to structure failure. Any sudden events such as earthquakes or heavy 
precipitation could have major impacts on the stability of the dam, thus posing a tremendous danger to nearby residential areas.

In table 1, we have listed the number of the dams and high hazard dams in the US together with annual average precipitation data and number of earthquake events from 1974 to 2003. This data is made available by US Army Corp of Engineers National Inventory of Dams.

Table 1: A summary of the Dams in the US as of May 2020. ${ }^{1}$ : High Hazard Dams [29, ${ }^{2}$ : Total number of Dams [29], ${ }^{3}$ : Percentage of Dams that are High Hazard, ${ }^{4}$ : Annual Avg Precipitation (in.) [30, ${ }^{5}$ :Total strong earthquakes in US from 1974 to 2003 31]

\begin{tabular}{|c|c|c|c|c|c|}
\hline State & Dams $^{1}$ & $\operatorname{Dams}^{2}$ & Percentage $^{3}$ & Precipitation $^{4}$ & Earthquake $^{5}$ \\
\hline Iowa & 99 & 4018 & 2.46 & 34.5 & 0 \\
\hline South Dakota & 90 & 2562 & 3.51 & 22.0 & 10 \\
\hline Minnesota & 53 & 1187 & 4.46 & 28.6 & 2 \\
\hline Kansas & 289 & 6403 & 4.51 & 32.4 & 4 \\
\hline Nebraska & 149 & 3007 & 4.95 & 26.6 & 8 \\
\hline North Dakota & 48 & 933 & 5.14 & 18.5 & 0 \\
\hline Wyoming & 99 & 1613 & 6.13 & 13.2 & 217 \\
\hline Mississippi & 381 & 6081 & 6.26 & 56.4 & 2 \\
\hline Montana & 221 & 3306 & 6.68 & 14.9 & 186 \\
\hline Louisiana & 46 & 609 & 7.55 & 59.14 & 1 \\
\hline Oklahoma & 449 & 4986 & 9.00 & 37.6 & 17 \\
\hline Florida & 101 & 1109 & 9.10 & 54.7 & 0 \\
\hline Alabama & 226 & 2273 & 9.94 & 56 & 15 \\
\hline Maine & 66 & 581 & 11.3 & 45.49 & 16 \\
\hline Georgia & 630 & 5306 & 11.8 & 50.2 & 7 \\
\hline Virginia & 356 & 2790 & 12.7 & 42.7 & 10 \\
\hline Illinois & 253 & 1662 & 15.2 & 38.5 & 17 \\
\hline Arkansas & 193 & 1263 & 15.2 & 49.7 & 34 \\
\hline South Carolina & 359 & 2343 & 15.3 & 49.2 & 10 \\
\hline Michigan & 172 & 1059 & 16.2 & 32.7 & 2 \\
\hline Vermont & 61 & 368 & 16.5 & 42.5 & 0 \\
\hline Oregon & 158 & 882 & 17.9 & 43.6 & 73 \\
\hline
\end{tabular}




\begin{tabular}{|l|r|r|r|r|r|}
\hline State & Dams & Dams $^{2}$ & Percentage $^{3}$ & Precipitation $^{4}$ & Earthquake $^{5}$ \\
\hline Wisconsin & 198 & 1065 & 18.5 & 33.1 & 0 \\
\hline Texas & 1411 & 7324 & 19.3 & 35 & 20 \\
\hline Idaho & 101 & 472 & 21.4 & 16.9 & 404 \\
\hline New York & 424 & 1934 & 21.9 & 42.9 & 16 \\
\hline Tennessee & 276 & 1241 & 22.2 & 51.8 & 22 \\
\hline Maryland & 91 & 400 & 22.8 & 42.1 & 0 \\
\hline New Hampshire & 160 & 652 & 24.5 & 44.8 & 6 \\
\hline Massachusetts & 328 & 1327 & 24.7 & 48.4 & 2 \\
\hline Kentucky & 272 & 1090 & 25.0 & 46.3 & 15 \\
\hline Colorado & 453 & 1803 & 25.1 & 17.0 & 24 \\
\hline Alaska & 28 & 107 & 26.1 & 29.0 & 12,053 \\
\hline Missouri & 1463 & 5379 & 27.2 & 42.5 & 21 \\
\hline New Jersey & 229 & 834 & 27.5 & 48.0 & 2 \\
\hline Indiana & 267 & 912 & 29.3 & 41.8 & 6 \\
\hline Ohio & 412 & 1407 & 29.3 & 39.2 & 8 \\
\hline Nevada & 156 & 525 & 29.7 & 9.46 & 778 \\
\hline Utah & 266 & 860 & 30.9 & 15.7 & 139 \\
\hline Connecticut & 284 & 845 & 33.6 & 50.0 & 0 \\
\hline Washington & 278 & 802 & 34.7 & 38.6 & 424 \\
\hline North Carolina & 1307 & 3191 & 41.0 & 46.9 & 3 \\
\hline Rhode Island & 96 & 234 & 41.0 & 49.9 & 1 \\
\hline Arizona & 164 & 376 & 43.6 & 11.8 & 32 \\
\hline California & 788 & 1576 & 50 & 22.9 & 4895 \\
\hline Pennsylvania & 797 & 1514 & 52.6 & 42.7 & 6 \\
\hline New Mexico & 219 & 407 & 53.8 & 14.2 & 38 \\
\hline West Virginia & 432 & 586 & 73.7 & 44.3 & 1 \\
\hline Delaware & 63 & 83 & 75.9 & 45.8 & 0 \\
\hline Hawaii & 122 & 133 & 91.7 & 50.3 & 1533 \\
\hline
\end{tabular}

The primary purpose of recording data regarding the number of high hazard dams, the average annual precipitation, and the total number of strong earthquakes from 1974 to 2003 per state is to highlight any patterns for specific states that may be at high risk of a dangerous and impactful dam failure. Both large amounts of precipitation and strong earthquakes are contributing factors to dam breakage. Seen through Table 1, most states have 0-50 earthquakes recorded from 1974 to 2003, but there are still a handful of states with extremely large numbers. Alaska, with the highest, has 12,053 earthquakes, California has 4,895, and Hawaii has 1,533. Moreover, although the number of high hazard dams per state has implications for the potential magnitude of effect that a dam break would have on neighboring areas, it is still important to note the total number of dams per state. Using both the total number of dams and the number of high hazard dams, a percentage of high hazard dams vs. total number of dams can be calculated. Because each state has individual factors that would contribute to varying number of total dams, seeing the percentage of high hazard dams helps to normalize the data. The table represents this data by 
sorting the information from the state with the lowest percentage of high hazard dams to the state with the highest percentage of high hazard dams.

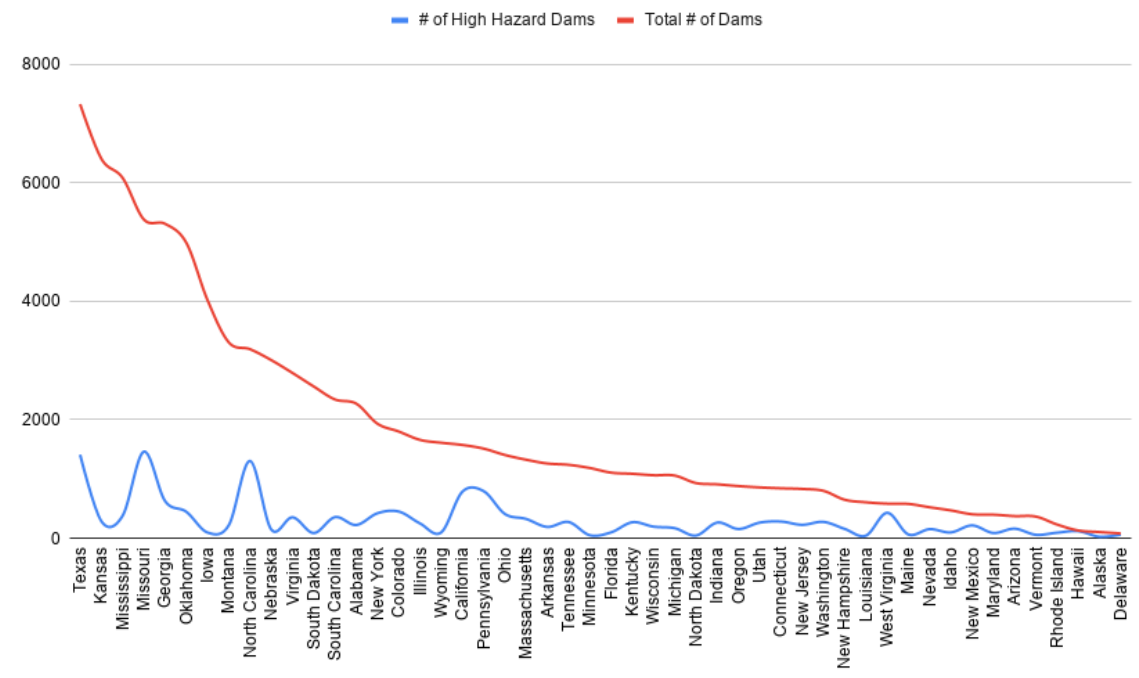

Figure 9: Total number of dams and high hazard dams

While some states like Iowa and South Dakota have a low number of high hazard dams in comparison to its total number of dams, there are quite a notable number of states that have a high percentage of high hazard dams. Figure 9 shows a visual representation of each state's total number of dams and its number of high hazard dams. The states to the left of the graph have the highest number of total dams. Based on the graph, states like Hawaii, Delaware, West Virginia, and New Mexico (states with the top 4 highest percentages) would have an extreme risk of residential destruction; any dam break in the state could result in a great loss of life as they have a high percentage of high hazard dams. 


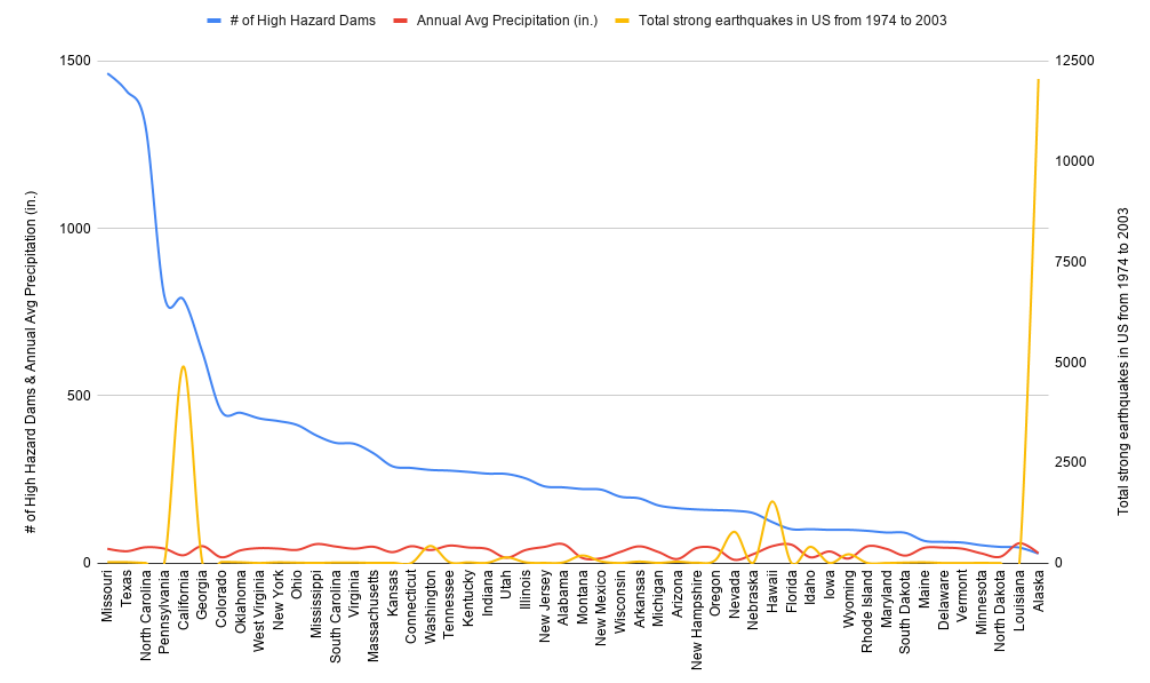

Figure 10: Total number of high hazard dams, average annual precipitation, and earth quake events per state

Overall, there appears to be little fluctuations in average annual precipitation across the states in comparison to the varying number of strong earthquakes per state according to Figure 10. For example, Alaska, California, and Hawaii have an extremely high number of strong earthquakes between 1974 and 2003. While Alaska and Hawaii have many earthquakes, they also have a relatively low number of high hazard dams in comparison to California with high numbers in both categorizes. This implies that California may be at an extremely high risk of dam breakage and residential destruction while Hawaii and Alaska are at less of a risk.

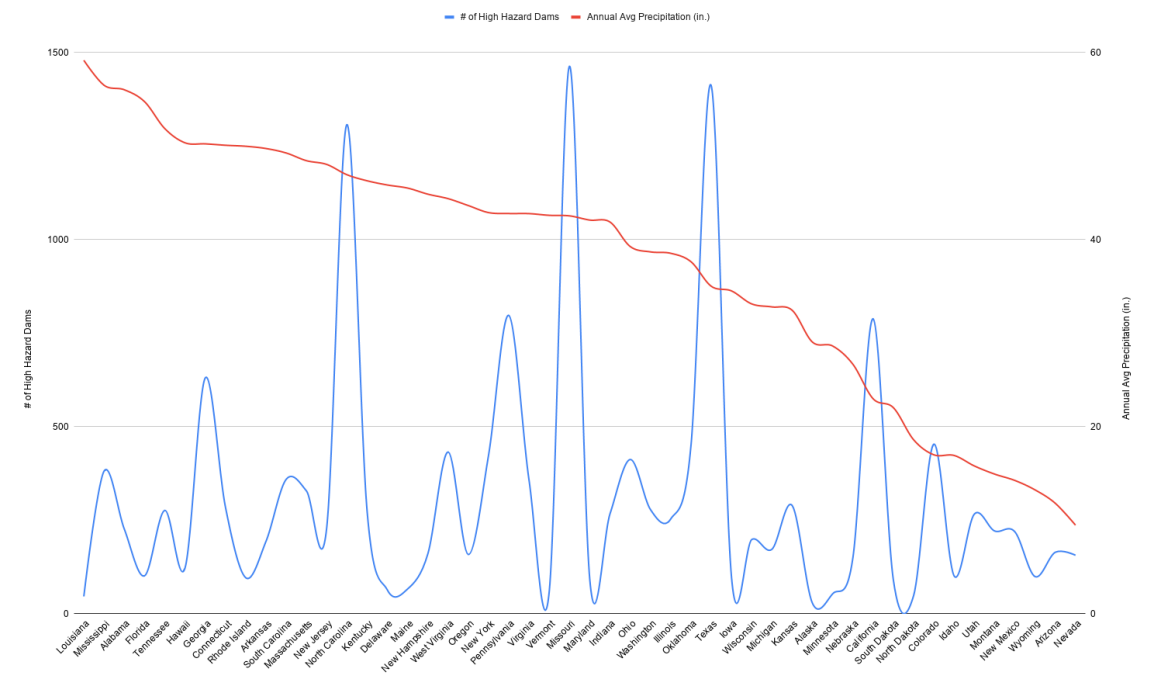

Figure 11: Total number of high hazard dams and average annual precipitation per state Figure 11 shows the number of high hazard dams per state along with the average annual 
precipitation decreasing from left to right. Some states with a large number of high hazard dams and annual average precipitation include North Carolina, Missouri, and Texas. This means that these few states are at a great risk of dam structure failure a potential dam breakage would have immense effects on neighboring areas due to its heavy precipitation and large surrounding population. States like California and Colorado have a large number of high hazard dams but have relatively low annual precipitation as they are located on the right half of the graph. There are several states like Georgia and Pennsylvania that have extremely high annual precipitation but slightly less high hazard dams than extreme states like North Carolina, Missouri, and Texas. Regardless, these states should be noted as they have a large potential for dam breakage and can still harm many nearby residents.

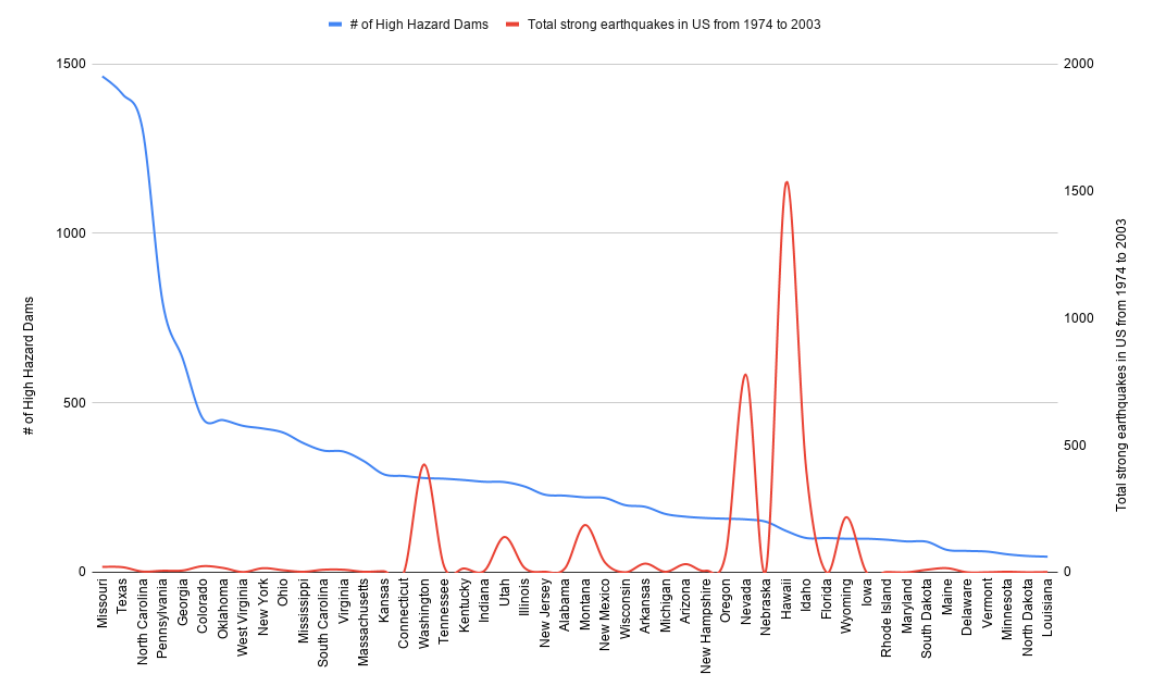

Figure 12: Total number of high hazard dams and earth quake events from 1974-2003 per state

Due to the outliers Hawaii and Nevada, which have an extremely large number of total strong earthquakes from 1974 to 2003, many of the states appear to have a relatively low number of earthquakes. However, it is still evident that there are a handful of states at risk of dam breakage and could have drastic effects on adjacent towns. As previously mentioned, Hawaii and Nevada have the highest peaks of earthquakes according to Figure 12, meaning they have the greatest number of earthquakes and are at a high risk of dam structure failure. However, these two states are found on the right half of the graph, meaning they have a fairly low number of high hazard dams (the number of high hazard dams per state decreases from left to right). As a result, Hawaii and Nevada may have a significant potential for dam breakage but may not harm too many residents. On the other hand, Washington has the third most number of earthquakes and is on the left half of the graph, with more high hazard dams than Hawaii and Nevada. Therefore, this implies that Washington has a fairly high risk of dam breakage and may even negatively harm a large population of residents. Some other notable states include Utah, Minnesota, and Wyoming, all of which have moderately high amounts of annual precipitation but lower numbers for the number of high hazard dams. 


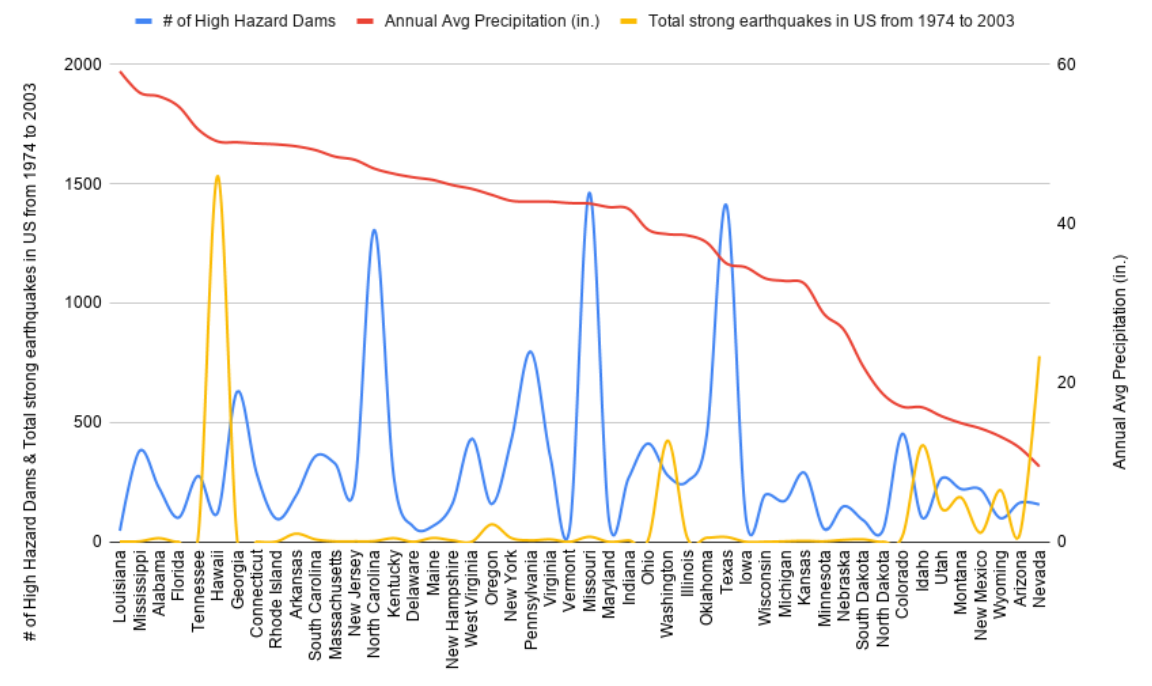

Figure 13: Total number of high hazard dams, average annual precipitation, and earth quake events per state. Two states California and Alaska are removed from this Figure since the number of Earthquakes are skewing the graph. Original data can be found in table 1

Figure 13 illustrates all three of the factors that contribute to the potential for dam breakage and its impacts per state. The states are organized from left to right by decreasing annual average precipitation. Overall, there are several states with high numbers in at least two of the categories. For example, as already previously noted, Hawaii has an extremely high number of total strong earthquakes from 1974 to 2003 as well as annual average precipitation, making this state extremely susceptible to dam breakage. Its heavier and more frequent precipitation and earth movement may cause its dams to fall victim to destruction. Fortunately, Hawaii does not have a relatively high number of high hazard dams, signifying that if a dam break were to occur, it would not have effects on a significantly large group of individuals. Moreover, states like North Carolina, Missouri, and Texas have a large number of high hazard dams as well as annual average precipitation. Although these three states do not have a relatively high number of total strong earthquakes, having high numbers in the two categories mentions indicates that the heavy precipitation could be a likely source for potential dam breaks and that a potential dam break would have adverse effects on a large group of residents.

Table 2: States with high number of Earthquakes

\begin{tabular}{|l|c|c|}
\hline State & High Hazard Dams & Earthquake \\
\hline Alaska & 28 & 12,053 \\
\hline California & 788 & 4895 \\
\hline Hawaii & 122 & 1533 \\
\hline Washington & 278 & 424 \\
\hline Montana & 221 & 186 \\
\hline Utah & 266 & 139 \\
\hline
\end{tabular}


Table 3: States with high annual average precipitation

\begin{tabular}{|l|r|r|}
\hline State & High Hazard Dams & Precipitation \\
\hline Georgia & 630 & 50.2 \\
\hline North Carolina & 1307 & 46.9 \\
\hline Pennsylvania & 797 & 42.7 \\
\hline Missouri & 1463 & 42.5 \\
\hline Texas & 1411 & 35 \\
\hline California & 788 & 22.9 \\
\hline
\end{tabular}

In summary, table 2 and table 3 show lists of States with large number of high hazard dams that are vulnerable to either Earthquake events or precipitation. It should be noted that California shows up in both tables.

\section{Conclusion}

Recent development of the social-political debate around the use of the mining tailings dam near Hoyt Lake City, Minnesota spurred our interest in examining the environmental impacts of a hypothetical dam break in the area. Our results indicate significant flooding in the downstream waterways if the tailings dams were to fail. It is difficult to estimate the social and economical cost of the pollution and interruption to the local area based on the seriousness of the potential risk from the simulated result.

This work focuses on the storage unit on the left of the tailings dam, though there are two more smaller storage units on the right that can potentially lead to a cascading dam break 33 . which could cause more significant failures than the result reported in this work. Future work can simulate the effect of a cascading dam break on the developed inundation map downstream.

Additional work can look into how other modes of failure can affect the simulated result of dam break as done similarly in [34] and [35]. Two modes of failure can be modelled in HECRAS. Our work is based on the overtopping method but we can also experiment with piping method.

As discussed by McDonald [15], dam breach characteristics are dependent on the exact nature how the breach occurred; in our study, a hypothetical breach is modelled in HEC RAS. Although our trial simulations of different breach set ups led to similar inundation map and hydrograph results, it will be interesting to analyze the local tailings dam to set up more accurate breach plans for the simulation.

In both the overtopping and piping failure modes we could examine the sensitivity of downstream hydrograph to breach parameters used in the simulation. The result presented in this work is based on overtopping failure using the parameters shown in Figure 14. The bottom width, Weir coefficient, formation time, slopes could all have an effect on the result [16] [24] [36]. It will be interesting to determine what these effects are through sensitivity studies and compare them with documented results from historical dam breaks. 


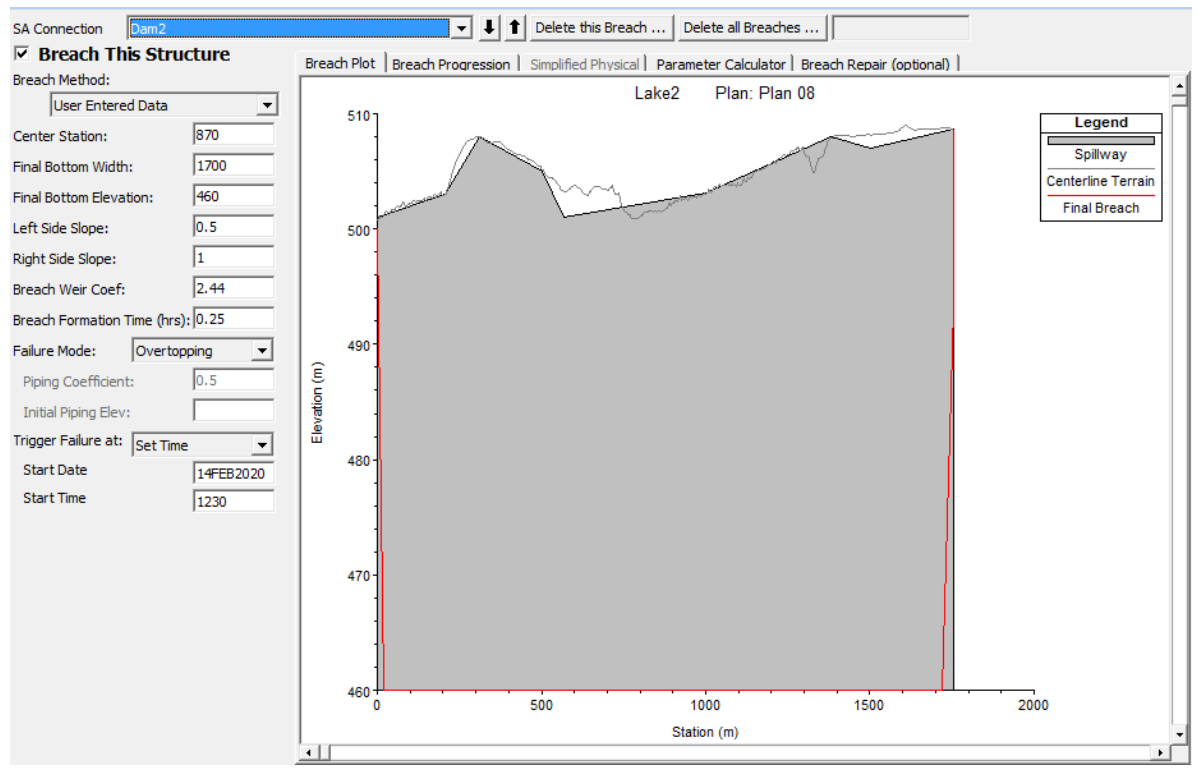

Figure 14: Breach parameters used for overtopping failure at the dam

The computational mesh used in the numerical simulation has a resolution of 100x100 meters, which is significantly coarser than the $1 / 3$ arc second digital elevation data downloaded from USGS. Higher resolution simulations can potentially improve the accuracy of the modeling result at the expense of much longer simulation time. Future work can investigate the effect of higher resolution simulations on the downstream inundation pattern, mud flow speed and depth as well.

We hope the result from this work can assist the local community near the LVT tailings dam and local government agencies to assess the potential risk of a dam failure. While the result presented is preliminary, we believe the simulated flooding pattern is indicative of what would happen if a dam failure was to occur.

Alarmed by the recent dam breaks in Michigan and the lack of maintenance of aging dams, we surveyed all the dams in the US, tabulating the number of dams and high hazard dams in each State in the US. Together with recorded Earthquake events and annual average precipitation, two lists of States with high hazard dams that are vulnerable to either Earthquake or precipitation are provided.

\section{References}

[1] minnpost.com (2019), A dam collapse in Brazil has some worried about PolyMet's plans. Why the DNR says it won't happen here. https://www.minnpost.com/environment/2019/08/a-dam-collapse-in-brazil-has-someworried-about-polymets-plans-why-the-dnr-says-it-wont-happen-here/ Retrieved 14 March, 2020

[2] virginiamn.com (2019), With Precious Metals in Need, Focus Shifts to PolyMet Dam. https://www.virginiamn.com/mine/with-precious-metals-in-need-focus-shifts-topolymet-dam/article_aefa7cb8-f9eb-11e9-8e93-6b77305446dc.html Retrieved 14 March, 2020 
[3] USGS.GOV, https://nationalmap.gov/ Retrieved 23 October, 2019

[4] Science Engineering and Sustainability (2019), Science Engineering and Sustainability: HEC-RAS evolution. https://sciengsustainability.blogspot.com/2016/08/some-months-agonew-version-of-hec-ras.html Retrieved 1 October 2019.

[5] US Army Corps of Engineers (2019), https://www.hec.usace.army.mil/software/hec-ras/ Retrieved 23 October, 2019

[6] dnr.state.mn.us, https://www.dnr.state.mn.us/polymet/permitting/index.html/ Retrieved 14 March, 2020

[7] PolyMet Mining, https://polymetmining.com/operations/northmet-snapshot/ Retrieved 14 March 2020

[8] industriallandscapes.org, $\quad$ https://www.industriallandscapes.org/mininglandscapes/erieltvpolymet-tailings-basin-hoyt-lakes-mn Retrieved 14 March 2020

[9] industriall-union.org, http://www.industriall-union.org/why-you-need-to-know-abouttailings-dams/ Retrieved 14 March 2020

[10] Klohn Crippen Berger (2018), Best Practices for Tailings Dam Design, https://www.klohn.com/blog/best-practices-for-tailings-dam-design/ Retrieved 28 October 2019 .

[11] Phillips, Dom (2020), https://www.theguardian.com/world/2020/jan/21/brazil-damcollapse-mining-disaster-charges/ Retrieved 14 March 2020

[12] GISGeography (2018), The Remarkable History of GIS. https://gisgeography.com/historyof-gis/ Retrieved 28 October 2019.

[13] Devantier, B. A. (1993), TP-144, Review of GIS Applications in Hydrologic Modeling

[14] Raman, A. and Liu, F. (2019), An investigation of the Brumadinho Dam Break with HEC RAS simulation, arXiv:1911.05219 [physics.comp-ph]

[15] McDonald, T. C. and Langridge-Monopolis F, (1984), BREACHING CHARACTERISTICS OF DAM FAILURES, Journal of Hydraulic Engineering Vol. 110, Issue 5

[16] Froehlich, David. (2008). Embankment Dam Breach Parameters and Their Uncertainties. Journal of Hydraulic Engineering-asce - J HYDRAUL ENG-ASCE. 134. 10.1061/(ASCE)0733-9429(2008)134:12(1708).

[17] Lariyah, M.S et al, (2013), Numerical modelling dam break analysis for water supply project, 4th International Conference on Energy and Environment

[18] Sidek L Y, Ros F C, Ibrahim N N N, Razad A Z A and Ahmad M N 2013 Hydrodynamic Dam Breach Modelling of Earthfill Saddle Dam J. of Energy and Environment 
[19] Peng, A. and Liu, F. (2019), Flooding simulation due to Hurricane Florence in NorthCarolina with HEC RAS, arXiv:1911.05219 [physics.comp-ph]

[20] mprnews.org https://www.mprnews.org/story/2019/01/09/minnesota-smashes-all-timestate-precipitation-record-in-2018 Retrieved 14 March 2020

[21] minnpost.com https://www.minnpost.com/environment/2018/12/yes-there-areearthquakes-in-the-land-of-10000-lakes/ Retrieved 14 March 2020

[22] files.dnr.state.mn.us https://files.dnr.state.mn.us/lands_minerals/northmet/dam-safety/04dam-safety-fof.pdf Retrieved March 212020

[23] US Army Corps of Engineers, (2016), HEC-RAS 5.0 Reference Manual, pp 2-52

[24] US Army Corps of Engineers, (2014), Using HEC-RAS for Dam Break Studies.

[25] epsg.io https://epsg.io/ Retrieved March 282020

[26] https://www.nytimes.com/2020/05/19/us/michigan-dam-breach.html Retrieved 6 June 2020

[27] https://www.mlive.com/news/saginaw-bay-city/2020/06/michigan-rates-6-dams-in-poorcondition-and-as-high-hazards-to-downstream-residents.html Retrieved 6 June 2020

[28] https://wwmt.com/news/local/after-edenville-dam-failure-5-others-rate-at-same-conditionand-risk-level-in-michigan Retrieved 6 June 2020

[29] National Inventory of Dams, https://nid.sec.usace.army.mil/ords/f?p=105:1:::::: Retrieved 14 March 2020

[30] https://www.currentresults.com/Weather/US/average-annual-state-precipitation.php Retrieved 14 March 2020

[31] https://www.usgs.gov/natural-hazards/earthquake-hazards/lists-maps-and-statistics

[32] HOOGESTRAAT G.K. (2011), Flood hydrology and dam-breach hydraulic analyses of four reservoirs in the Black Hills, South Dakota. Science Investigation Repport 2011- 5011. Reston, Virginia. USGS pp. 37.

[33] Pillai B R K, Saibal Ghosh and Gupta O P (2012), Integrated Dam Break Analysis "Case Study of Indira Sagar and Omkareshwar Projects India Water Week 2012" Water, Energy and Food Security : Call for Solutions 10-14 April 2012, New Delhi

[34] Xiong, Y. A (2011), Dam Break Analysis Using HEC-RAS, Journal of Water Resource and Protection, 2011, 3, 370-379

[35] Kilania, S. (2019), A Dam Break Analysis Using HEC-RAS, World Environmental and Water Resources Congress 2019, May 162019

[36] Wahl, Tony L. (2009), Evaluation of New Models for Simulating Embankment Dam Breach. Association of State Dam Safety Officials (ASDO) Conference, Hollywood, Florida 